\title{
Uji Toksisitas Akut Ekstrak Etanol 70\% Daun Tegining Ganang (Cassia planisiliqua Burm.F.) Terhadap Mencit Jantan (Mus musculus L.)
}

\author{
Sister Sianturi", Amelia Febriani, Mia Aty Dolok Rosa Manalu
}

Program Studi S1 Farmasi, Institut Sains dan Teknologi Nasional, Jl. M. Kahfii II, Srengseng Sawah, Jakarta Selatan, 12640

E-mail: $\underline{\text { sianturisister@istn.ac.id }}$

\begin{abstract}
Abstrak
Daun tegining ganang (Cassia planisiliqua Burm.f.) merupakan salah satu tumbuhan berkhasiat di Lombok. Berdasarkan pengalaman empiris masyarakat, daun tegining ganang dapat mengobati sakit perut, muntaber, maag, nyeri ulu hati, nyeri pinggang, batu ginjal, dan lain-lain. Penelitian ini bertujuan untuk mengetahui $\mathrm{LD}_{50}$ sehingga didapatkan tingkat toksisitas sediaan uji, dan efek toksik yang dihasilkan dari daun tegining ganang. Penelitian dilakukan dengan cara serbuk tegining ganang dimaserasi menggunakan etanol 70\%, kemudian diuapkan dengan rotary vacum evaporator. Kemudian dilakukan uji organoleptis, bebas pelarut etanol, dan penapisan fitokimia. Pengujian toksisitas akut dilakukan dengan cara memberikan sediaan uji pada 4 kelompok mencit jantan pada dosis $800 \mathrm{mg} / \mathrm{kgBB}, 1600 \mathrm{mg} / \mathrm{kgBB}, 3200 \mathrm{mg} / \mathrm{kgBB}$ dengan batas uji $5000 \mathrm{mg} / \mathrm{kgBB}$, dan suspensi CMC Na $1 \%$ sebagai kontrol negatif secara oral. Setelah pemberian, dilakukan pengamatan tanda toksisitas pada 4 jam pertama, kemudian pengamatan tanda toksisitas setelah 24 jam dan selama 14 hari dan dilakukan pengamatan efek toksik tertunda. Dari hasil penelitian didapatkan nilai $\mathrm{LD}_{50}$ semu $\left(\mathrm{LD}_{0}\right) 3200 \mathrm{mg}$ dengan kategori praktis tidak toksik dan tidak ada gejala klinis ketoksikan akut yang signifikan yang terjadi pada seluruh hewan coba.
\end{abstract}

Kata kunci: toksisitas, ekstrak, tegining, Cassia

\section{Pendahuluan}

Daun tegining ganang (Cassia planisiliqua Burm.f.) merupakan salah satu tumbuhan berkhasiat yang tumbuh di Lombok. Berdasarkan pengalaman empiris masyarakat, daun tegining ganang dapat mengobati penyakit dalam, seperti sakit perut, muntaber, maag, nyeri ulu hati, nyeri pinggang, batu ginjal, keracunan, diabetes, dan hipertensi. Sebagai obat luar, seperti gigitan binatang, tanaman beracun, ikan beracun, gatal-gatal pada kulit, luka, ambeien, dan lain-lain [1]. Kandungan kimia yang terdapat pada daun tegining ganang antara lain sitronelal, tumeron, asam hexadekanoat, oksasikloheptadek, neofitatadin, asam palmitat, asam stearat, glikosida antrakuinon, flavonoid, alkaloid, fitosterol, saponin, tanin, galaktomanan, polisakarida, dan terpenoid $[1,2,3]$.

Penelitian sebelumnya menunjukkan bahwa ekstrak etanol $70 \%$ daun tegining ganang diketahui memiliki aktivitas analgesik. Efek analgesik yang dimiliki daun tegining ganang diperoleh sebesar $98,90 \%$ pada dosis 800 $\mathrm{mg} / \mathrm{kg} \mathrm{BB}$ mencit yang hampir sama dengan efektivitas asetosal pada dosis $650 \mathrm{mg} / \mathrm{kg}$ BB mencit sebesar $100 \%$. Penelitian lain menunjukkan bahwa ekstrak etanolik daun tegining ganang pada dosis $200 \mathrm{mg} / \mathrm{kgBB}$ dan 400 $\mathrm{mg} / \mathrm{kgBB}$ mempunyai efek mengurangi inflamasi pada tapak kaki mencit $[3,4]$.

Toksisitas akut dengan parameter dosis letal median $\mathrm{LD}_{50}$ memberikan petunjuk tentang dosis yang sebaiknya digunakan dalam waktu lama. $\mathrm{LD}_{50}$ merupakan dosis tunggal suatu zat yang diharapkan akan membunuh 50\% hewan coba, selain itu dari uji toksisitas akut dapat diketahui kategori toksisitas bahan [5].

Setiap bahan atau zat kimia yang merupakan obat harus diteliti sifat toksiknya sebelum diperbolehkan penggunaannya secara luas, agar obat tradisional dapat diterima dikalangan masyarakat. Khasiat empiris juga harus didukung oleh bukti-bukti ilmiah adanya manfaat klinik dalam pencegahan atau pengobatan penyakit dan tidak menyebabkan efek samping serius dalam arti aman untuk pemakaian obat pada manusia. Oleh sebab itu perlu dilakukan uji toksisitas akut daun tegining ganang untuk melihat ada tidaknya efek toksik pada hewan uji $[6,7]$.

Pengujian toksisitas akut pada penelitian ini menggunakan metode konvensional berdasarkan ketentuan Peraturan Kepala Badan Pengawas Obat dan Makanan No. 7 tahun 2014 tentang Pedoman Uji Toksisitas Nonklinik Secara In Vivo, hewan uji yang digunakan adalah mencit jantan galur Dutche Danken Yoken (DDY) yang terbagi menjadi 4 kelompok uji dengan masing-masing kelompok terdiri atas 6 ekor mencit pada dosis $800 \mathrm{mg} / \mathrm{kg}$ BB mencit, $1600 \mathrm{mg} / \mathrm{kg}$ BB mencit, $3200 \mathrm{mg} / \mathrm{kg}$ BB mencit dengan batas dosis maksimum $5000 \mathrm{mg} / \mathrm{kgBB}$, dan suspensi $\mathrm{Na}$ CMC $1 \%$ sebagai kontrol negatif.

Parameter toksisitas yang diamati adalah $\mathrm{LD}_{50}$, pengamatan tanda toksisitas pada 4 jam pertama (jam ke$0,0,5,1,2,3,4)$ yang meliputi pengamatan pada sistem 
kardiovaskuler, pernafasan, kulit, dan bulu, selain itu pengamatan akan adanya tremor, kejang, salivasi, letargi, lemah, tidur, koma, perubahan berat badan, jumlah hewan yang mati, kemudian pengamatan anda toksisitas setelah 24 jam yang meliputi pengamatan pada sistem kardiovaskuler, pernafasan, kulit, dan bulu, selain itu pengamatan akan adanya tremor, kejang, salivasi, letargi, lemah, tidur, koma, perubahan berat badan, jumlah hewan yang mati, dan setelah itu sehari sekali selama 14 hari untuk pengamatan efek toksik tertunda yang meliputi pengamatan pada sistem kardiovaskuler, pernafasan, kulit, dan bulu, pengamatan akan adanya tremor, kejang, salivasi, letargi, lemah, tidur, koma, perubahan berat badan, jumlah hewan yang mati. Nilai $\mathrm{LD}_{50}$ dihitung dengan metode Thompson \& Weil dengan parameter yang diamati adalah semua hewan yang mati, baik yang mati dengan sendirinya atau yang mati dalam keadaan moribound digabungkan jumlahnya untuk perhitungan nilai $\mathrm{LD}_{50}[8]$.

\section{Metode}

\subsection{Umum}

Bahan uji yang digunakan adalah daun tegining ganang (Cassia planisiliqua Burm.f.) segar sebanyak 1,6 $\mathrm{kg}$ yang didapatkan dari perkebunan di Daerah Narmada Desa Peresak Kabupaten Lombok Barat Provinsi Nusa Tenggara Barat. Hewan uji yang digunakan dalam penelitian adalah mencit berjenis kelamin jantan, sehat, galur Dutche Danken Yoken (DDY), berusia 6-8 minggu dengan bobot 23-26 g. Pengujian toksisitas akut berdasarkan ketentuan Peraturan Kepala Badan Pengawas Obat Dan Makanan No. 7 tahun 2014 tentang Pedoman Uji Toksisitas Nonklinik Secara In Vivo.

\subsection{Penyiapan Sampel}

Bahan uji yang digunakan yaitu daun yang masih segar dan masih muda. Daun tegining ganang yang telah dikumpulkan selanjutnya disortasi basah untuk memisahkan cemaran dari bahan baku dan untuk mengurangi jumlah kontaminasi mikroba tanah. Daun yang telah disortasi basah kemudian dicuci dengan air mengalir untuk membersihkan bahan baku dari kotoran atau tanah yang masih menempel. Daun yang telah dicuci, selanjutnya dikeringkan pada suhu ruangan hingga kering. Daun yang telah dikeringkan, selanjutnya disortasi kering untuk memisahkan bahan baku dari kotoran yang mungkin masih tercampur. Daun yang telah disortasi kering, selanjutnya diserbukkan dan diayak dengan nomor pengayak 60 untuk memperoleh bahan baku dalam bentuk serbuk.

\subsection{Ekstraksi}

Serbuk kering tegining ganang diekstraksi sebanyak 285 g secara maserasi menggunakan etanol 70\%. Selama 6 jam pertama sambil sekali-kali diaduk, kemudian diamkan selama 18 jam. Maserat diperoleh dengan cara pengendapan. Kemudian dilakukan remaserasi sebanyak 2 kali dengan jenis dan jumlah pelarut yang sama. Semua maserat dikumpulkan, kemudian diuapkan dengan rotary vacum evaporator pada suhu $40^{\circ} \mathrm{C}$ lalu dipekatkan di penangas air pada suhu $40^{\circ} \mathrm{C}$ sampai didapatkan ekstrak kental. Rendemen ekstrak dihitung dengan rumus:

$$
\% \text { rendemen }=\frac{\text { Bobot ekstrak kental }}{\text { Bobot simplisia }} \times 100 \%
$$

\subsection{Penapisan Fitokimia}

\section{Alkaloid}

Sebanyak 2 gram ekstrak dilembabkan dengan $5 \mathrm{ml}$ Amoniak 25\% didalam gelas beker, kemudian ditambahkan $20 \mathrm{ml}$ Kloroform hingga massa terendam, diaduk dan dipanaskan diatas penangas air lalu disaring. Filtrat diuapkan sampai setengahnya. Sisa penguapan dituang kedalam tabung reaksi dan ditambah $1 \mathrm{ml}$ Asam Klorida $2 \mathrm{~N}$, kemudian dikocok hingga membentuk 2 lapisan, lapisan jernih yang terbentuk dimasukkan kedalam 3 tabung reaksi dengan jumlah yang sama. Kemudian ditambahkan pereaksi mayer pada tabung I, pereaksi Bouchardat pada tabung II, pereaksi Dragendorf pada tabung III. Terdapatnya alkaloid ditandai dengan terbentuknya endapan putih pada pereaksi Mayer, endapan coklat pada pereaksi Bouchardat, endapan merah pada pereaksi Dragendorf.

\section{Flavonoid}

Sebanyak 1 gram ekstrak diekstraksi dengan air panas $100 \mathrm{ml}$ kemudian disaring. Filtrat sebanyak $5 \mathrm{ml}$ dimasukkan kedalam tabung reaksi, kedalam larutan percobaan ditambahkan $1 \mathrm{ml}$ larutan Sodium Nitrat 5\% dan $1 \mathrm{ml}$ Aluminium Klorida 10\%, dikocok kemudian ditambahkan $2 \mathrm{ml}$ Natrium Hidroksida $1 \mathrm{~N}$ melalui dinding tabung. Jika positif mengandung flavonoid warna akan berubah menjadi merah atau jingga.

\section{Saponin}

Sebanyak 1 gram ekstrak ditambahkan dengan air panas $100 \mathrm{ml}$ kemudian disaring. Filtrat sebanyak $10 \mathrm{ml}$ dimasukkan kedalam tabung reaksi, dikocok vertikal selama 10 detik. Hasil positif saponin ditandai dengan terbentuknya buih yang mantap setinggi 1 hingga $10 \mathrm{~cm}$. Pada penambahan Asam Klorida $2 \mathrm{~N}$ buih tidak hilang, maka hal tersebut menunjukkan adanya senyawa golongan saponin.

\section{Tanin}

Sebanyak 1 gram ekstrak ditambahkan dengan air panas $100 \mathrm{ml}$ kemudian disaring. Filtrat sebanyak $5 \mathrm{ml}$ kemudian dimasukkan kedalam tabung reaksi kemudian ditambahkan beberapa tetes Ferri (III) Klorida 1\%. Hasil positif mengandung tanin menunjukkan terbentuknya warna hijau ungu, atau hitam.

\section{Steroid/Triterpenoid}

Sebanyak 2 gram ekstrak dimaserasi dengan $20 \mathrm{ml}$ Eter selama 2 jam, kemudian disaring dan diuapkan dalam cawan penguap hingga diperoleh residu, tambahkan 2 tetes Asetat Anhidrat dan $2 \mathrm{ml}$ Kloroform kedalam residu tersebut, lalu pindahkan kedalam tabung reaksi. Kemudian ditambahkan perlahan-lahan $1 \mathrm{ml}$ Asam Sulfat Pekat 
melalui dinding tabung. Lihat lapisan cincin yang terbentuk. Hasil positif triterpenoid menunjukkan terbentuknya cincin berwarna merah ungu, sedangkan untuk steroid ditandai dengan warna hijau.

\subsection{Uji Toksisitas Akut}

Hewan uji yang digunakan dalam penelitian adalah mencit berjenis kelamin jantan, sehat, galur Dutche Danken Yoken (DDY), berusia 6-8 minggu dengan bobot 23 g-26 g. Sebelum pemberian sediaan uji, mencit di aklimatisasi selama 7 hari serta diberi makan dan minum ad libitum. Pembagian kelompok hewan uji dapat dilihat pada Tabel 1.

Tabel 1. Pembagian kelompok hewan uji

\begin{tabular}{ccc}
\hline Kelompok & Perlakuan & BB Mencit \\
\hline K1 & Ekstrak $(800 \mathrm{mg} / \mathrm{kgBB})$ & $25 \mathrm{~g}$ \\
$\mathrm{~K} 2$ & Ekstrak $(1600 \mathrm{mg} / \mathrm{kgBB})$ & $24 \mathrm{~g}$ \\
$\mathrm{~K} 3$ & Ekstrak $(3200 \mathrm{mg} / \mathrm{kgBB})$ & $23 \mathrm{~g}$ \\
$\mathrm{~K} 4$ & CMC-Na $1 \%$ (kontrol -) & $26 \mathrm{~g}$ \\
\hline
\end{tabular}

Dosis uji toksisitas akut yang diberikan pada hewan uji menggunakan dosis tertinggi yang tidak menimbulkan kematian dari hasil penelitian sebelumnya yaitu $800 \mathrm{mg} / \mathrm{kg}$ $\mathrm{BB}$, kemudian digunakan kelipatan dua setiap tingkatan dosis menjadi $1600 \mathrm{mg} / \mathrm{kg} \mathrm{BB}, 3200 \mathrm{mg} / \mathrm{kg}$ BB mencit [3].

Tabel 2. Perhitungan dosis uji

\begin{tabular}{cccc}
\hline Kelompok & $\begin{array}{c}\text { BB } \\
\text { Mencit }\end{array}$ & Perlakuan & $\begin{array}{c}\text { Dosis/ } \\
\text { Kelompok } \\
\text { (6 ekor) }\end{array}$ \\
\hline K1 & $25 \mathrm{~g}$ & $\begin{array}{c}\text { Ekstrak }(800 \\
\mathrm{mg} / \mathrm{kgBB})\end{array}$ & $120 \mathrm{mg}$ \\
$\mathrm{K} 2$ & $24 \mathrm{~g}$ & $\begin{array}{c}\text { Ekstrak }(1600 \\
\mathrm{mg} / \mathrm{kgBB})\end{array}$ & $228 \mathrm{mg}$ \\
$\mathrm{K} 3$ & $23 \mathrm{~g}$ & $\begin{array}{c}\text { Ekstrak } \\
(3200 \mathrm{mg} / \mathrm{kgBB}) \\
\text { CMC Na 1\% }\end{array}$ & $444 \mathrm{mg}$ \\
$\mathrm{K} 4$ & $26 \mathrm{~g}$ & $\begin{array}{c}\text { (kontrol negatif) } \\
\text { (kont }\end{array}$ \\
\hline
\end{tabular}

\section{Pembuatan Larutan Kontrol Negatif}

Larutan CMC Na 1\% dibuat dengan cara menimbang $1 \mathrm{~g}$ serbuk CMC Na kemudian dimasukkan ke dalam mortir kemudian ditambahkan $20 \mathrm{ml}$ air panas sedikit demi sedikit hingga mengembang sambil diaduk. Setelah terbentuk suspensi kemudian dimasukkan kedalam labu ukur tambahkan sisa air panas hingga $100 \mathrm{ml}$ lalu dimasukkan kedalam mortir gerus hingga homogen.

\section{Pemberian Sediaan Uji dan Kontrol Negatif}

Mencit jantan dipuasakan sebelum diberikan perlakuan mencit selama 3-4 jam dan diberikan air minum tanpa batas (ad libitum). Setelah dipuasakan, mencit ditimbang dan diberikan sediaan uji. Sediaan uji diberikan dalam dosis bertingkat secara oral dengan menggunakan sonde. Setelah diberikan perlakuan, pakan diberikan kembali setelah 1-2 jam.

\section{Pengamatan}

Uji toksisitas akut ditentukan dengan pengamatan yang meliputi waktu timbul dan hilangnya gejala toksik serta terjadinya kematian yang disebabkan oleh pemberian dosis bertingkat sediaan uji pada kelompok mencit dengan dosis $800 \mathrm{mg} / \mathrm{kg} \mathrm{BB}, 1600 \mathrm{mg} / \mathrm{Kg} \mathrm{BB}, 3200 \mathrm{mg} / \mathrm{kg} \mathrm{BB}$. Setelah pemberian dilakukan pengamatan tanda toksisitas pada 4 jam pertama (jam ke $0,0,5,1,2,3,4$ ) meliputi pengamatan tanda toksisitas pada sistem kardiovaskuler, pernafasan, kulit, dan bulu, selain itu pengamatan akan adanya tremor, kejang, salivasi, letargi, lemah, tidur, koma, perubahan berat badan, jumlah hewan yang mati.

Kemudian pengamatan tanda toksisitas setelah 24 jam yang meliputi pengamatan tanda toksisitas pada sistem kardiovaskuler, pernafasan, kulit, dan bulu, selain itu pengamatan akan adanya tremor, kejang, salivasi, letargi, lemah, tidur, koma, perubahan berat badan, jumlah hewan yang mati. Setelah itu sehari sekali selama 14 hari untuk pengamatan efek toksik tertunda yang meliputi pengamatan pada sistem kardiovaskuler, pernafasan, kulit, dan bulu, pengamatan akan adanya tremor, kejang, salivasi, letargi, lemah, tidur, koma, perubahan berat badan, jumlah hewan yang mati. Hewan yang sekarat dimasukkan sebagai perhitungan hewan mati.

\subsection{Analisis Data}

Hasil pengamatan tanda-tanda toksisitas digunakan sebagai data kualitatif untuk mengevaluasi penyebab kematian. Data jumlah hewan yang mati pada masingmasing kelompok digunakan sebagai data kuantitatif untuk menghitung $\mathrm{LD}_{50}$. Bila sampai dengan batas volume maksimum yang boleh diberikan pada hewan uji dan dosis yang diberikan tidak menimbulkan kematian pada hewan uji, maka dosis tersebut dinyatakan sebagai $\mathrm{LD}_{50}$ semu $\left(\mathrm{LD}_{0}\right)$. Hasil pengamatan rata-rata berat badan mencit yang diperoleh dari kelompok hewan uji selanjutnya dianalisis secara statistik dengan menggunakan perangkat lunak SPSS version 17. Analasisis statistik yang digunakan adalah Uji Levene untuk mengetahui homogenitas varian dari beberapa kelompok dan Uji Shapiro-Wilk untuk mengetahui data tersebut terdistribusi normal atau tidak. Data tersebut digunakan sebagai salah satu syarat untuk Uji Parametrik. Jika data tersebut homogen dan normal maka dilanjutkan dengan Uji Anova dan dilanjutkan analisis lebih lanjut apabila ada perbedaan bermakna. Uji lebih lanjut dilakukan dengan Uji Duncan-W. Jika data tersebut tidak terdistribusi normal dan tidak homogen maka perlu dilakukan Uji Non Parametrik dengan menggunakan Kruskal Wallis untuk mengetahui perbedaan antar kelompok lalu dilanjutkan dengan Uji Mann Whitney.

\section{Hasil dan Pembahasan}

\subsection{Ekstraksi}

Pembuatan serbuk bertujuan untuk meningkatkan luas permukaan dari simplisia, umumnya penyarian akan bertambah baik bila permukaan serbuk simplisia yang bersentuhan dengan cairan penyari makin luas [10]. Hasil rendemen serbuk yang didapatkan yaitu 32,5\%. Hasil rendemen serbuk yang didapatkan dari penelitian sebelumnya yaitu 23,07\% [3].

Ekstraksi bertujuan untuk menarik dan memisahkan berbagai komponen kimia yang terdapat dalam bahan alam dengan menggunakan pelarut organik tertentu [11]. 
Ekstraksi yang digunakan dalam penelitian ini menggunakan metode maserasi. Karena metode ini tergolong sederhana dan cepat tetapi sudah dapat menyari zat aktif dari simplisia dengan maksimal serta dapat mencegah rusaknya atau hilangnya zat aktif yang ingin disari [12].

Pelarut yang digunakan dalam maserasi yaitu etanol $70 \%$. Etanol digunakan sebagai cairan penyari karena pelarut etanol merupakan pelarut universal yang dapat menarik senyawa-senyawa yang dapat larut dalam pelarut polar hingga non polar, lebih efektif, tidak beracun, netral, absorbsinya baik, dapat bercampur dengan air pada segala perbandingan. Selain itu etanol dengan konsentrasi 70\% sangat efektif dalam menghasilkan jumlah bahan aktif yang optimal [26,27]. Hasil ekstraksi etanol 70\% daun tegining ganang yang didapatkan yaitu 122,6 g dengan rendemen ekstrak yaitu $43 \%$. Hasil ekstraksi yang didapatkan dari penelitian sebelumnya yaitu $72,13 \mathrm{~g}$ dengan rendemen ekstrak yaitu $18,03 \%$.

\subsection{Pemeriksaan Organoleptis}

Pemeriksaan organoleptis ekstrak dilakukan dengan tujuan untuk pemeriksaan awal yang sederhana meliputi bentuk, warna, rasa, bau dari ekstrak yang diperoleh [14]. Hasil pemeriksaan organoleptis pada ekstrak daun tegining ganang yaitu bentuk ekstrak kental, berwarna hitam, rasa pahit, dan bau khas. Rasa pahit yang terdapat pada ekstrak daun tegining ganang kemungkinan berasal dari senyawa kimia yang terkandung dalam daun tegining ganang yaitu alkaloid. Secara organoleptik, daun yang berasa sepat dan pahit biasanya teridentifikasi mengandung alkaloid. Fungsi alkaloid bagi tumbuhan sebagai pelindung tumbuhan dari serangan hama dan penyakit, pengatur tumbuh atau sebagai basa mineral untuk mempertahankan keseimbangan ion [15]. Tujuan dari pemeriksaan bebas pelarut yaitu untuk mengetahui apakah ekstrak yang diperoleh masih mengandung etanol atau tidak, sehingga tidak memengaruhi hasil uji toksisitas akut yang dilakukan. Hasil pemeriksaan bebas pelarut etanol pada ekstrak daun tegining ganang yaitu negatif mengandung etanol ditandai dengan tidak terbentuk endapan kuning dan tidak terdapat bau iodoform.

Tabel 3. Hasil pemeriksaan organoleptis ekstrak

\begin{tabular}{ccc}
\hline No & Uji Organoleptis & Hasil Pemeriksaan \\
\hline 1 & Bentuk & Ekstrak kental \\
2 & Warna & Hitam \\
3 & Rasa & Pahit \\
4 & Bau & Khas \\
\hline
\end{tabular}

\subsection{Penapisan Fitokimia}

Penapisan fitokimia dilakukan dengan tujuan untuk memberikan gambaran metabolit sekunder yang terdapat pada simplisia yang diujikan [14]. Hasil penapisan fitokimia ekstrak daun tegining ganang yang didapatkan positif mengandung alkaloid, saponin dengan tinggi $3 \mathrm{~cm}$, tanin, dan triterpenoid, flavonoid. Hasil penapisan fitoimia tersebut sedikit berbeda dengan hasil penapisan fitokimia sebelumnya. Pada penelitian sebelumnya hasil penapisan fitokimia yang didapatkan antara lain alkaloid, phenol, flavonoid, tannin, steroid, saponin, terpenoid [2]. Pada penelitian lain hasil penapisan fitokimia yang didapatkan antara lain alkaloid, flavonoid, saponin, tannin, dan steroid. Perbedaan tersebut dipengaruhi karena metabolit sekunder diproduksi organisme [3] tertentu dalam kondisi spesifik yang dipengaruhi oleh faktor ketinggian tempat, curah hujan, kondisi hara tanah, perbedaan wilayah tumbuh mengakibatkan kandungan senyawa kimia yang berbeda [16].

Tabel 4. Hasil penapisan fitokimia

\begin{tabular}{|c|c|c|c|}
\hline Identifikasi & Pereaksi & Hasil & Kesimpulan \\
\hline \multirow{3}{*}{ Alkaloid } & Mayer & $\begin{array}{l}\text { Tidak terbentuk } \\
\text { endapan putih }\end{array}$ & 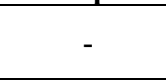 \\
\hline & Dragendorf & $\begin{array}{l}\text { Terbentuk } \\
\text { endapan merah } \\
\text { bata }\end{array}$ & + \\
\hline & Bouchardat & $\begin{array}{l}\text { Terbentuk } \\
\text { endapan coklat }\end{array}$ & + \\
\hline Flavonoid & $\begin{array}{l}\mathrm{NaNO}_{3} \\
\mathrm{AlCl}_{3} 10 \% \\
\mathrm{NaOH} 0,1 \\
\mathrm{~N}\end{array}$ & $\begin{array}{l}\text { Terbentuk warna } \\
\text { merah/jingga }\end{array}$ & +++ \\
\hline Saponin & $\mathrm{HCl} 2 \mathrm{~N}$ & $\begin{array}{l}\text { Terbentuk buih } \\
3 \mathrm{~cm} \text { dan buih } \\
\text { tidak hilang }\end{array}$ & +++ \\
\hline Tanin & $\mathrm{FeCl}_{3} 1 \%$ & $\begin{array}{l}\text { Terbentuk warna } \\
\text { hijau kehitaman }\end{array}$ & + \\
\hline $\begin{array}{l}\text { Steroid/ } \\
\text { Triterpenoid }\end{array}$ & $\begin{array}{l}\mathrm{CHCl}_{3} \\
\mathrm{CH}_{3} \mathrm{COOH}_{\mathrm{H}} \\
\mathrm{H}_{2} \mathrm{SO}_{4} \text { pekat }\end{array}$ & $\begin{array}{l}\text { Terbentuk cincin } \\
\text { warna merah } \\
\text { ungu }\end{array}$ & ++ \\
\hline
\end{tabular}

Keterangan:

(-) : Hasil pengujian negatif pada kandungan yang diujikan.

$(+)$ : Hasil pengujian positif pada kandungan yang diujikan terlihat kurang jelas.

$(++)$ : Hasil pengujian positif pada kandungan yang diujikan terlihat jelas.

$(+++)$ : Hasil pengujian positif pada kandungan yang diujikan terlihat sangat jelas.

\subsection{Uji Toksisitas}

\section{Uji Toksisitas Akut 4 Jam dan 24 Jam}

Pengamatan tanda toksiksitas pada 4 jam dan 24 jam setelah perlakuan (jam ke $0,0,5,1,2,3,4,24$ ) untuk melihat efek toksik yang ditimbulkan. Pada kelompok 1 (dosis $800 \mathrm{mg} / \mathrm{kgBB}$ ) terdapat tanda toksisitas pada kardiovaskuler ditandai dengan jantung berdebar cepat (jam ke- 1 dan 2), pada pernafasan ditandai dengan pernafasan menurun (jam ke- 1, 2, dan 3), pada kulit ditandai dengan kulit terasa gatal (jam ke- 2 dan 3), lemah ditandai dengan aktivitas menurun (jam ke- 1, 2, 3, 4), tidur pada jam ke- 4 dan terdapat penurunan berat badan yang sedikit setelah 24 jam.

Kelompok 2 (dosis $1600 \mathrm{mg} / \mathrm{kgBB}$ ) memperlhatkan tanda toksisitas pada kardiovaskuler ditandai dengan jantung berdebar cepat (jam ke- 0 dan 0,5 ), pada pernafasan ditandai dengan pernafasan menurun (jam ke- 0,5 , dan 1 ), pada kulit ditandai dengan kulit terasa gatal (jam ke- 0,5 , 1), lemah ditandai dengan aktivitas menurun (jam ke- 1, 2, $3,4)$, tidur pada jam ke- 2, 3 dan 4 dan terdapat penurunan berat badan yang sedikit setelah 24 jam. 
Tabel 5. Hasil pengamatan tanda toksiksitas selama 4 jam dan 24 jam

\begin{tabular}{|c|c|c|c|c|c|c|c|c|}
\hline \multirow{2}{*}{ Kelompok } & \multirow{2}{*}{$\begin{array}{c}\text { Parameter } \\
\text { Pengamatan }\end{array}$} & \multicolumn{7}{|c|}{ Jam Ke- } \\
\hline & & $\mathbf{0}$ & 0,5 & 1 & 2 & 3 & 4 & 24 \\
\hline \multirow{14}{*}{ Kelompok 1} & Kardiovaskuler & - & - & + & + & - & - & - \\
\hline & Pernafasan & - & - & + & + & + & - & - \\
\hline & Kulit & - & - & - & + & + & - & - \\
\hline & Bulu & - & - & - & - & - & - & - \\
\hline & Mata & - & - & - & - & - & - & - \\
\hline & Tremor & - & - & - & - & - & - & - \\
\hline & Kejang & - & - & - & - & - & - & - \\
\hline & Salivasi & - & - & - & - & - & - & - \\
\hline & Diare & - & - & - & - & - & - & - \\
\hline & Lemah & - & - & + & + & + & + & - \\
\hline & Tidur & - & - & - & - & - & + & - \\
\hline & Koma & - & - & - & - & - & - & - \\
\hline & Mati & - & - & - & - & - & - & - \\
\hline & Berat Badan & - & - & - & - & - & - & + \\
\hline \multirow{14}{*}{ Kelompok 2} & Kardiovaskuler & + & + & - & - & - & - & - \\
\hline & Pernafasan & + & + & + & - & - & - & - \\
\hline & Kulit & - & + & + & - & - & - & - \\
\hline & Bulu & - & - & - & - & - & - & - \\
\hline & Mata & - & - & - & - & - & - & - \\
\hline & Tremor & - & - & - & - & - & - & - \\
\hline & Kejang & - & - & - & - & - & - & - \\
\hline & Salivasi & - & - & - & - & - & - & - \\
\hline & Diare & - & - & - & - & - & - & - \\
\hline & Lemah & - & - & + & + & + & + & - \\
\hline & Tidur & - & - & - & + & + & + & - \\
\hline & Koma & - & - & - & - & - & - & - \\
\hline & Mati & - & - & - & - & - & - & - \\
\hline & Berat Badan & - & - & - & - & - & - & + \\
\hline \multirow{14}{*}{ Kelompok 3} & Kardiovaskuler & + & + & - & - & - & - & - \\
\hline & Pernafasan & + & + & + & - & - & - & - \\
\hline & Kulit & + & + & - & - & - & - & - \\
\hline & Bulu & - & - & - & - & - & - & - \\
\hline & Mata & - & - & - & - & - & - & - \\
\hline & Tremor & + & - & - & - & - & - & - \\
\hline & Kejang & - & - & - & - & - & - & - \\
\hline & Salivasi & - & - & - & - & - & - & - \\
\hline & Diare & - & - & - & - & - & - & - \\
\hline & Lemah & - & + & + & + & + & + & - \\
\hline & Tidur & - & - & + & + & + & + & - \\
\hline & Koma & - & - & - & - & - & - & - \\
\hline & Mati & - & - & - & - & - & - & - \\
\hline & Berat Badan & - & - & - & - & - & - & + \\
\hline \multirow{14}{*}{ Kelompok 4} & Kardiovaskuler & - & - & - & - & - & - & - \\
\hline & Pernafasan & - & - & - & - & - & - & - \\
\hline & Kulit & - & - & - & - & - & - & - \\
\hline & Bulu & - & - & - & - & - & - & - \\
\hline & Mata & - & - & - & - & - & - & - \\
\hline & Tremor & - & - & - & - & - & - & - \\
\hline & Kejang & - & - & - & - & - & - & - \\
\hline & Salivasi & - & - & - & - & - & - & - \\
\hline & Diare & - & - & - & - & - & - & - \\
\hline & Lemah & - & - & - & - & - & - & - \\
\hline & Tidur & - & - & - & - & - & - & - \\
\hline & Koma & - & - & - & - & - & - & - \\
\hline & Mati & - & - & - & - & - & - & - \\
\hline & Berat Badan & - & - & - & - & - & - & - \\
\hline
\end{tabular}

Keterangan:

$(+)$ : terdapat tanda toksisitas

$(-)$ : tidak terdapat tanda toksisitas 
Kelompok 3 (dosis $3200 \mathrm{mg} / \mathrm{kgBB}$ ) menunjukkan tanda toksisitas pada kardiovasuler ditandai dengan jantung berdebar cepat (jam ke- 0 dan 0,5 ), pada pernafasan ditandai dengan pernafasan menurun (jam ke- $0,5,1,2$ ), pada kulit ditandai dengan kulit terasa gatal (jam ke- 0,5, 1), lemah ditandai dengan aktivitas menurun (jam ke- 0,5 , $1,2,3,4)$, tremor ditandai dengan badan gemetar (jam ke1), tidur pada jam ke- 1, 2, 3 dan 4 dan terdapat penurunan berat badan yang sedikit setelah 24 jam.

Tanda toksisitas dan penurunan berat badan yang terdapat pada kelompok 1, 2 dan 3 kemungkinan terjadi karena dosis yang digunakan tinggi dan dipengaruhi oleh kandungan kimia yang dikandung dari ekstrak daun tegining ganang yang bersifat toksik yang kemungkinan merupakan golongan alkaloid. Berdasarkan literatur banyak alkaloid beracun bagi organisme lain, alkaloid tersebut bersifat toksik, biotoksisitas dari alkaloid tergantung dari organisme dan struktur kimia alkaloid tersebut [17]. Pada kelompok 4 tidak terdapat tanda toksisitas, dan tidak terdapat kematian pada hewan uji, hal ini karena kelompok hewan uji pada kelompok 4 hanya diberi kontrol negatif suspensi CMC Na $1 \%$ yang bersifat tidak toksik dan tidak menyebabkan iritan [18].

Tabel 6. Penurunan rata-rata berat badan dan jumlah kematian hewan uji setelah 24 jam

\begin{tabular}{cccc}
\hline Kelompok & $\begin{array}{c}\text { BB awal } \\
(\text { g) }\end{array}$ & $\begin{array}{c}\text { Rata-Rata } \\
\text { BB 24 jam } \\
\text { (g) } \pm \text { SD }\end{array}$ & $\begin{array}{c}\text { Jumlah } \\
\text { Kematian } \\
\text { Setelah 24 } \\
\text { Jam }\end{array}$ \\
\hline Kelompok 1 & 25 & $24 \pm 0,63$ & 0 \\
Kelompok 2 & 24 & $22,83 \pm 0,75$ & 0 \\
Kelompok 3 & 23 & $22,16 \pm 0,98$ & 0 \\
Kelompok 4 & 26 & $26,6 \pm 0,4$ & 0 \\
\hline
\end{tabular}

\section{Pengamatan Efek Toksik Tertunda Selama 14 Hari}

Pengamatan efek toksik tertunda selama 14 hari dilakukan untuk mengetahui efek toksik yang tidak terdapat pada pengamatan 24 jam sebelumnya serta jumlah kematian hewan uji sebagai parameter nilai $\mathrm{LD}_{50}$.

Hasil pengamatan memperlihatkan kelompok 1, 2, dan 3 terdapat terdapat tanda toksisitas hanya pada hari ke1 dan pada hari ke- 2 hingga hari ke-14 tidak terdapat tanda toksisitas, hal ini disebabkan karena efek toksisitas yang sudah di eliminasi melalui ekskresi. Sementara itu pada kelompok 4 tidak menunjukkan tanda toksisitas. Hal ini karena kelompok hewan uji pada kelompok 4 hanya diberi kontrol negatif suspensi CMC Na 1\% yang bersifat tidak toksik dan tidak menyebabkan iritan [18].

Setelah 1 hari pada kelompok 2 terdapat 1 ekor mencit yang terlihat tanda toksisitas pada hari ke- 2, 3, 4, 5, 6 yang meliputi pada pernafasan ditandai dengan pernafasan menurun, lemah yang ditandai dengan aktivitas yang menurun, tidur hingga mati pada hari ke- 6. Hal ini kemungkinan karena dosis yang digunakan tinggi dan dipengaruhi oleh kandungan kimia yang dikandung dari ekstrak daun tegining ganang yang bersifat toksik. Senyawa tersebut kemungkinan alkaloid .Beberapa alkaloid beracun bagi organisme lain, alkaloid tersebut bersifat toksik, biotoksisitas dari alkaloid tergantung dari organisme dan struktur kimia alkaloid tersebut [17].
Tabel 7. Hasil pengamatan efek toksik tertunda selama 14 hari

\begin{tabular}{cl}
\hline Kelompok & \multicolumn{1}{c}{ Efek yang Ditimbulkan } \\
\hline Kelompok 1 & $\begin{array}{l}\text { Tidak terdapat tanda tokisitas pada hari ke-1 } \\
\text { hingga ke-14 }\end{array}$ \\
\hline Kelompok 2 & $\begin{array}{l}\text { Hanya pada 1 ekor mencit yang terdapat } \\
\text { tanda toksisitas yaitu pernafasan menurun, } \\
\text { lemah, tidur hingga mati. }\end{array}$ \\
\hline Kelompok 3 & $\begin{array}{l}\text { Tidak terdapat tanda tokisitas pada hari ke-1 } \\
\text { hingga ke-14 }\end{array}$ \\
\hline Kelompok 4 & $\begin{array}{l}\text { Tidak terdapat tanda tokisitas pada hari ke-1 } \\
\text { hingga ke-14 }\end{array}$ \\
\hline
\end{tabular}

\section{Pengamatan Berat Badan selama 14 hari}

Pengamatan berat badan selama 14 hari bertujuan untuk mengetahui hubungan sediaan uji ekstrak daun tegining ganang terhadap perubahan rata-rata berat badan mencit selama 14 hari. Hasil pengamatan berat badan selama 14 hari menunjukkan penurunan berat badan pada kelompok 1, 2, dan 3 hanya pada hari ke- 1 dan dibandingkan dengan kelompok 4 (kontrol negatif) yang tidak mengalami penurunan berat badan yang signifikan. Pada hari ke- 2 hingga hari ke- 14 terdapat kenaikan berat badan pada kelompok 1, 2, 3. Hal ini disebabkan karena efek toksisitas yang sudah dieliminasi melalui ekskresi.

Tabel 8. Hasil Pengamatan Rata-Rata Berat Badan \pm SD Hewan Uji Selama 14 Hari

\begin{tabular}{ccccc}
\hline Hari & \multicolumn{4}{c}{ Rata-Rata Berat Badan \pm SD } \\
\cline { 2 - 5 } Ke- & $\mathbf{K 1}$ & $\mathbf{K 2}$ & $\mathbf{K 3}$ & $\mathbf{K 4}$ \\
\hline 0 & $25 \pm 0$ & $24 \pm 0$ & $23 \pm 0$ & $26 \pm 0$ \\
1 & $24 \pm 0,63$ & $22,9 \pm 0,75$ & $22,3 \pm 0,81$ & $26,7 \pm 1,21$ \\
2 & $28,2 \pm 1,16$ & $25,5 \pm 2,8$ & $25,8 \pm 0,75$ & $29,5 \pm 0,54$ \\
3 & $29,5 \pm 1,51$ & $26,7 \pm 3,44$ & $27,8 \pm 0,98$ & $30,7 \pm 1,5$ \\
4 & $30,5 \pm 1,03$ & $27,8 \pm 4,07$ & $28,5 \pm 1,64$ & $32,2 \pm 1,69$ \\
5 & $30,5 \pm 1,37$ & $28,17 \pm 4,62$ & $29,2 \pm 1,72$ & $33,3 \pm 2,34$ \\
6 & $31,9 \pm 1,72$ & $28,7 \pm 5,95$ & $30,7 \pm 1,5$ & $34,5 \pm 2,34$ \\
7 & $32,3 \pm 1,36$ & $26 \pm 1,64$ & $30,7 \pm 1,03$ & $34,5 \pm 2,13$ \\
8 & $32,9 \pm 1,47$ & $26,7 \pm 1,87$ & $30,3 \pm 1,21$ & $35,2 \pm 2,28$ \\
9 & $33,3 \pm 1,75$ & $27 \pm 1,51$ & $31,3 \pm 0,81$ & $36 \pm 2,34$ \\
10 & $33,9 \pm 1,72$ & $27,5 \pm 1,87$ & $31,9 \pm 1,16$ & $36,5 \pm 2,13$ \\
11 & $32,3 \pm 1,21$ & $26,7 \pm 2,91$ & $32 \pm 1,09$ & $37,2 \pm 2,25$ \\
12 & $34,3 \pm 1,86$ & $27,6 \pm 2,28$ & $32,7 \pm 1,21$ & $37,7 \pm 2,16$ \\
13 & $35 \pm 2,09$ & $28,3 \pm 2,44$ & $32,9 \pm 1,16$ & $38,3 \pm 2,5$ \\
14 & $36,3 \pm 2,16$ & $29,3 \pm 2,05$ & $34,3 \pm 1,36$ & $40,3 \pm 2,59$ \\
\hline
\end{tabular}

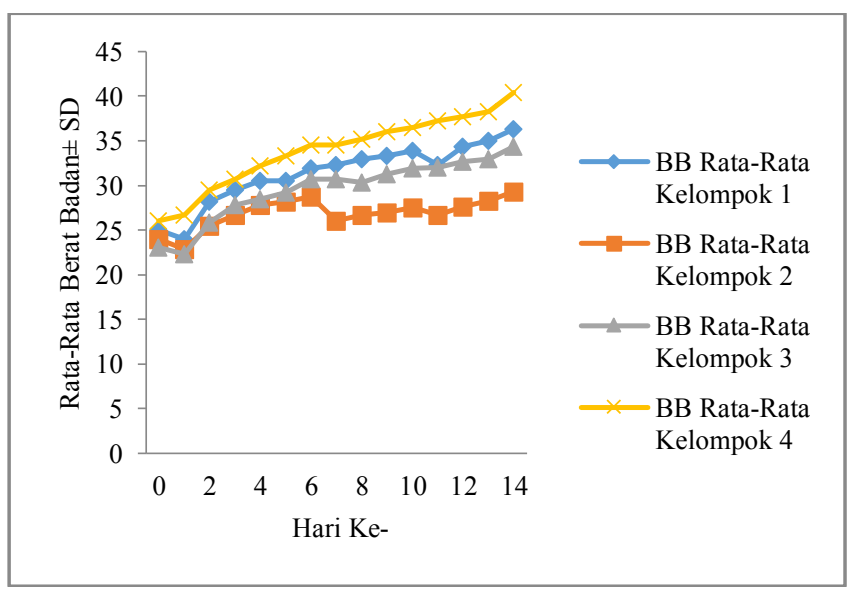

Gambar 1. Grafik Rata-Rata Berat Badan Hewan Uji \pm SD Selama 14 Hari 
Kelompok 2 memperlihatkan penurunan berat badan yang signifikan hanya pada 1 ekor mencit pada hari ke-1, 2, 3, 4, 5. Hal ini kemungkinan dipengaruhi kandungan kimia yang dikandung dari ektrak daun tegining ganang. Kandungan kimia tersebut kemungkinan alkaloid. Berdasarkan literatur banyak alkaloid beracun bagi organisme lain, alkaloid tersebut bersifat toksik, biotoksisitas dari alkaloid tergantung dari organisme dan struktur kimia alkaloid tersebut [18]. Kelompok 4 sendiri menunjukkan kenaikan berat badan selama 14 hari. Hal ini karena kelompok hewan uji pada kelompok 4 hanya diberi kontrol negatif suspensi CMC Na 1\% yang bersifat tidak toksik dan tidak menyebabkan iritan [18].

\section{Penentuan Nilai $L D_{50}$}

Penentuan nilai $\mathrm{LD}_{50}$ diperoleh menggunakan rumus Thompson dan Weil. metode ini dipilih karena mempunyai tingkat kepercayaan yang cukup tinggi dan merupakan metode yang paling sering digunakan, metode ini juga menggunakan daftar perhitungan $\mathrm{LD}_{50}$ sehingga hasil yang diperoleh lebih akurat [19]. Perhitungan LD $_{50}$ memperlihatkan tidak adanya nilai $\mathrm{R}$ pada tabel Weil karena hanya 1 ekor mencit yang mati pada kelompok ke2 sehingga nilai $\mathrm{R}$ yang didapat adalah $0,1,0$, 0 . Hasil tersebut dapat diabaikan karena hanya terjadi padal ekor mencit (tidak mencapai 50\%), yang mungkin disebabkan oleh faktor lain diluar efek yang disebabkan oleh sediaan uji daun tegining ganang. Kematian tersebut dapat disebabkan adanya kesalahan pada saat pemberian sediaan.

Jika dosis maksimal tidak menimbulkan kematian hewan coba, maka $\mathrm{LD}_{50}$ dinyatakan dengan $\mathrm{LD}_{50}$ semu dengan mengambil dosis maksimal. Sehingga dalam penelitian ini $\mathrm{LD}_{50}$ diketahui sebagai $\mathrm{LD}_{50}$ semu, yaitu $3200 \mathrm{mg} / \mathrm{kgBB}$. Hasil ini tidak dapat dimasukkan dalam kriteria Loomis, karena $\mathrm{LD}_{50}$ yang didapat bukan merupakan LD $_{50}$ yang sesungguhnya [20]. Apabila pada dosis maksimal tidak ada kematian pada hewan coba, maka jelas senyawa tersebut termasuk dalam kriteria "Praktis Tidak Toksik". Sehingga dosis maksimal pada manusia yang dikonversikan menjadi $800 \mathrm{mg} / \mathrm{kgBB}, 1600$ $\mathrm{mg} / \mathrm{kgBB}, 3200 \mathrm{mg} / \mathrm{kgBB}$ pada mencit, di mana dosis tersebut tidak menimbulkan kematian pada hewan uji [20].

Tabel 12. Jumlah Kematian Hewan Uji Selama 14 Hari

\begin{tabular}{clc}
\hline $\begin{array}{c}\text { Nama } \\
\text { Kelompok }\end{array}$ & \multicolumn{1}{c}{ Dosis } & $\begin{array}{c}\text { Jumlah } \\
\text { Kematian }\end{array}$ \\
\hline Kelompok 1 & $\begin{array}{l}\text { Ekstrak Daun Tegining } \\
\text { Ganang 800 mg/kgBB }\end{array}$ & 0 \\
\hline Kelompok 2 & $\begin{array}{l}\text { Ekstrak Daun Tegining } \\
\text { Ganang 1600 mg/kgBB }\end{array}$ & 1 \\
\hline Kelompok 3 & $\begin{array}{l}\text { Ekstrak Daun Tegining } \\
\text { Ganang 3200 mg/kgBB }\end{array}$ & 0 \\
\hline Kelompok 4 & Suspensi CMC Na 1\% & 0 \\
\hline
\end{tabular}

\section{Uji Statistik}

Hasil statistik Uji Levene menunjukkan bahwa data rata-rata berat badan kelompok 1, 2, 3, dan 4 teristribusi normal $(\mathrm{p}>0.05)$. Kemudian dilanjutkan dengan Uji Shapiro-Wilk yang menunjukkan bahwa data rata-rata berat badan tersebut terdistribusi homogen $(p>0,05)$.
Kemudian dilanjutkan dengan uji Anova yang menunjukkan bahwa data tersebut terdapat perbedaan bermakna $(\mathrm{p}<0,05)$. Kemudian dilanjutkan dengan uji lebih lanjut (Post Hoc Test) Duncan-W yang menunjukkan data rata-rata berat badan pada kelompok 1 (ekstrak daun tegining ganang dosis $800 \mathrm{mg} / \mathrm{kgBB}$ ), kelompok 2 (ekstrak daun tegining ganang dosis $1600 \mathrm{mg} / \mathrm{kgBB}$ ) dan kelompok 3 (ekstrak daun tegining ganang dosis $3200 \mathrm{mg} / \mathrm{gBB}$ ) tidak ada perbedaan bermakna ditandai dengan terdapat pada kolom yang sama.

Pada kelompok 2 (ekstrak daun tegining ganang dosis $1600 \mathrm{mg} / \mathrm{kgBB}$ ) dan kelompok 3 (ekstrak daun tegining ganang dosis $3200 \mathrm{mg} / \mathrm{gBB}$ ) terdapat perbedaan bermakna dibandingkan dengan kelompok 4 (kontrol negatif) ditandai dengan tidak terdapat pada kolom yang sama. Data ratarata berat badan kelompok 1 dan 4 tidak terdapat perbedaan bermakna ditandai dengan terdapat pada kolom yang sama.

\section{Kesimpulan}

Nilai $\mathrm{LD}_{50}$ ekstrak etanol $70 \%$ daun tegining ganang diketahui $\mathrm{LD}_{50}$ semu yaitu $3200 \mathrm{mg} / \mathrm{kgBB}$ termasuk dalam kriteria praktis tidak toksik, dan tidak menunjukkan adanya gejala klinis ketoksikan akut yang signifikan yang terjadi pada seluruh hewan coba.

\section{Ucapan Terima Kasih}

Peneliti mengucapkan terima kasih kepada: Direktorat Riset dan Pengabdian Masyarakat (DRPM) Kementerian Riset, Teknologi, dan Pendidikan Tinggi (Kemenristekdikti) atas bantuan dana yang diberikan melalui Hibah Penelitian Dosen Pemula 2018. Demikian juga kepada Bapak I Wayan Rusha Satya yang telah memiliki hak paten atas tanaman asli Lombok (Tegining ganang).

\section{Daftar Pustaka}

1. Sudarma IM, Kimia Bahan Alam. Mataram: Penerbit FMIPA Press. Universitas Mataram, 2006:13-20.

2. Aja PM, Ugwu Okechukwu PC, Kennedy K, Ibere JB, Ekpono EU, Phytochemical analys of Senna occidentalis leaves, IDOSR Journal Of Applied Science, 2017, 2(1);7591.

3. Satrana DK, Uji Efek Analgetik Ekstrak Etanol 70\% Daun Tegining Ganang (Cassia planisiliqua. Burm.F) pada mencit jantan (Mus musculus), Skripsi, Jakarta: Institut Sains dan Teknologi Nasional, 2017.

4. Benvenuto AF, Tasminatun. Uji Efek Antiinflamasi Ekstrak Etanol Daun Tegining-Ganang (Cassia planisiliqua) Pada Mencit (Mus musculus), Skripsi, Yogyakarta: Universitas Muhammadiyah Yogyakarta, 2007.

5. Lu C, Toksikologi Dasar: Asas Organ Sasaran Dan Penelitian Resiko, Edisi 2, Jakarta: UI Press, 1995: 74

6. Gani-Sulistia. Farmakologi dan Terapi, Edisi 4, Jakarta: Bagian Farmakologi, Fakultas Kedokteran Universitas Indonesia. Jakarta, 1995: 763

7. Tjokronegoro A, Baziad A, Etik Penelitian Obat Tradisional, Edisi 2, Jakarta: Universitas Indonesia, 1992: 14

8. Badan Pengawas Obat dan Makanan RI. Peraturan Kepala Badan Pengawas Obat dan Makanan Republik Indonesia Nomor 7 Tahun 2014 tentang Pedoman Uji Toksisitas Nonklinik Secara In Vivo. Jakarta. 
9. Sini KR, Sinha BN, Sangeetha PT, Analgesic and antipyretic activity of Cassia occidentalis Linn., Annals of Biological Research, 2011, 2(1);195-200

10. Voigt R, Buku Pelajaran Teknologi Farmasi, Diterjemahkan oleh Soendani Nurono Suwandi, Yogyakarta: UGM Press, 1995: 56

11. Departemen kesehatan Republik Indonesia. Sediaan Galenik. Jakarta: Direktorat Jenderal Pengawasan Obat dan Makanan, 1986: 4, 25

12. Sa'adah $H$, Nurhasnawati $H$, Perbandingan pelarut etanol dan air pada pembuatan ekstrak umbi bawang tiwai (Eleutherine americana Merr) menggunakan metode maserasi, Jurnal Ilmiah Manuntung, 2015, 1(2);144-153.

13. Padmasari PD, Astuti KW, Warditiani NK, Skrining fitokimia ekstrak etanol 70\% daun rimpang bangle (Zingiber purpureum Roxb.), Jurnal Farmasi Udayana, 2013, 2(4).

14. Departemen Kesehatan RI. Parameter Standard Umum Ekstrak Tumbuhan Obat. Jakarta: Direktorat Jenderal Pengawasan Obat dan Makanan, 2000; 1-2, 10-12.31-32.

15. Hammado N, Iling I, Identifikasi senyawa bahan aktif alkaloid pada tanaman lahuna (Eupatorium odoratum),
Jurnal Dinamika, 2013, 4(1);1-18.

16. Salim M, Yahya, Sitorus H, Nimah T, Marini, Kandungan hara tanah dengan produksi senyawa metablit sekunder pada tanaman duku (Lansium domesticum Corr var Duku) dan potensinya sebagai larvasida, Jurnal Vektor Penyakit, 2016, 10(1);11-18

17. Aniszewski T, Alkaloid-Secret Of Life, Edisi I, Amsterdam: Elsevier B. V., 2007;161.

18. Pamuji R, Uji toksisitas akut ekstrak etanol daun Sengkubak (Pycnarrhena cauliflora Diels) terhadap tikus betina galur istar dengan metode OECD 425. Jurnal Mahasiswa Farmasi Fakultas Kedokteran UNTAN, 2015, 3(1);1-11.

19. Nonci FY, Rusdi M, La Mohan IZF, Uji toksisitas akut ekstrak etanol klika jambu mede (Anacardium occidentale L.) pada mencit jantan (Mus musculus), JFFIK UINAM, 2014, 2(2);62-68

20. Armansyah TR, Indriany S, Sutriana A, Rosmaidar R, Asmilia N, Panjaitan B, Aliza D, Hamdan H, Uji toksisitas akut ekstrak etanol daun malaka (Phyllantus emblica) terhadap mencit (Mus musculus), Jurnal Kedokteran Hewan, 2016, 10(2);192-194. 